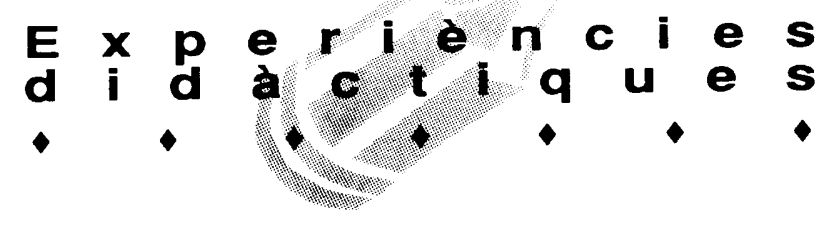

\title{
ACTIVITATS LÚDIQUES SOBRE UNA METODOLOGIA SERIOSA
}

\author{
Elena Arts Roca. Professora en tècniques de llenguatge i audició. Col.legi "San Rafael"
}

Ara que serbis i croats lluiten d'una maneratan cruel, caldria recordar que de la col.laboració d'especialistes d'ambdós països va sorgir la metodologia verbo-tonal, a partir de l'ensenyament de llengües estrangeres a Zagreb.

L'equip del Dr. Petar Guberina va idear un sistema d'estratègies didàctiques $i$ el material adient per vèncer les dificultats dels estudiants d'idiomes. Tot allò, aplicat a la reeducació dels sords, va donar excel.lents resultats en llur desmutització. Adequant-ho a les necessitats més especifiques d'aquests nens, varen crear el mètode verbotonal, el qual, com a conjunt de recursos per a faciltar el desenvolupament del llenguatge, pot ser útil, en molts aspectes, en el treball de l'aula de llengua de l'escola normal per als nens petits.

Tots sabem que el llenguatge sintetitza l'exercici de moltes funcions diferents: audició, pronúncia, ritme, lògica, evocació, motricitat global i fina, orientació en el temps i en l'espai... Això vol dir que una bona metodologia inclouràl'educació i el desenvolupament de totes aquestes funcions.

També sabem que els sentits, com a canals d'aprenentatge, tenen una jerarquia diferent $\mathrm{i}$ individual per a cada persona. El canal preferencial d'aprenentatge pot ser qualsevol i l'educador haurà de jugar exhaustivament amb tots els elements des del punt de vista de la polisensorialitat i de la individualitat.

Tenint en compte les afirmacions anteriors, la metodologia verbo-tonal proposa unes estratègies d'estructuració del llenguatge basades en tots els actes del llenguatge: mímica, ordres, endevinalles, projectes, evocacions, hipòtesis, metàfores, categoritzacions, lectura d'indicis, rimes, associació selectiva, expressió de somnis, mentides, seqüències dinàmiques sistemàtiques, crits, etc., etc.

Per iniciar el nen en tot això, ofereix les activitats següents: treballs amb contes, frases ritmades, cançonetes, calendaris, escenes de la vida del nen, jocs de lateralitat i sincronia entre grafisme i verbalització.

L'estructuració d'aquestes activitats passa per...

- Escoltar/col.laborar, és a dir, atenció auditival intercanvi de pensaments.

- Realitzar estructures kinestèsiques (no fonemàtiques, no codificades) com ara gestos i ritmes expressius que ens duran a una gramàtica del comportament.

- Explotar, per cada nen en particular, a) els trets somatogràfics i b) els indicis.

- Realitzar seqüències dinàmiques com a descobriments del sistema de la llengua. Aquí $s$ 'introdueixen totes les formes del discurs.

- Activar el saber a través d'estratègies instrumentals.

- Potenciar la creativitat a través de l'escriptura, la representació teatral, el joc i diverses formes de la imaginació manifestades en forma gràfica.

Si tenim en compte que el moviment és un comportament polisensorial, en farem un factor bàsic en tot el treball de reeducació, posant molta atenció al moviment global del cos (passos, salts...) i al de motricitat fina.

El ritme és el gran complement del moviment. com més atractiu sigui el ritme, millor. Ritme i moviment van lligats a les cançonetes $i$ a les frases ritmades. Al crearles, o seleccionar-les, s'haurà de tenir encompte el tema que volem tractar i els moviments que volem treballar. El tema ha de ser sobre coses viscudes pels nens $i$ amb continguts senzills.

Pels moviments haurem de seleccionar els aspectes següents:

1) Comportaments corporals adeqüats.

2) Ritmes convenients a cada part del cos.

3) Gestualitat explicativa de l'acció.

4) Rima de la cançó.

5) Un grafisme que evoqui el moviment realitzat i la fonètica de la cançó.

Les lletres de les cançonetes poden servir perconèixer el propi cos $\mathrm{i}$ el vocabulari corresponent, a més d'ajudar a la interiorització de les estructures sintàctiques que vagin apareixent. Exemple: 


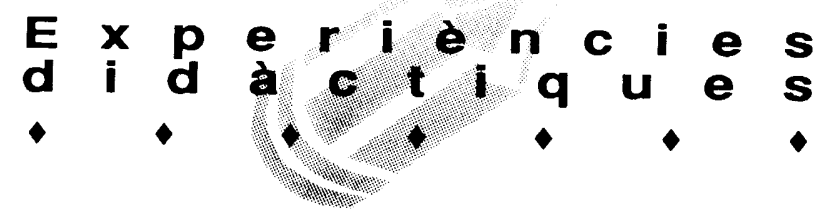

Tinc dos ulls,

tinc un nas,

dues orelles,

i una boca.

Tinc les mans per aplaudir, $i$ els peus, per caminar.

També poden referir-se a activitats quotidianes:

Menjo, menjo,

m'ho menjo tot.

Em rento, em rento,

em rento les mans,

em rento, em rento,

em rento les dents.

M'en vaig

a dormir.

O bé, ajuden a descobrir el cos del companys:

El meu nas, el teu nas.

La meva boca, la teva boca.

La meva mà, la teva mà.

Les meves mans, les teves mans.

Que bé!, Que bé!

Els moviments que acompanyen aquestes cançons són els d'asenyalar o tocar les parts del cos que es van anomenant, imitar les accions que es van dient, o saltar, agafats de les mans del company, quan es crida : "Que bé!"

El següent estadideltreballcorresponals grafismes. Els grafismes són moviments rítmics de la mà que acompanyen els sons de les cançons 0 de les frases ritmades i que es realitzen en l'aire, a la pissarra i sobre el paper. L'ordre d'aquest procés farà anar reduint , cada cop, l'amplitud dels moviments.

Els contes són un altre apartat dins de les activitats proposades. Cada conte treballa un tema del programa escolar i dura dues sessions amb les etapes següents:

1) Explicar la lliçó mitjançant un conte infantil amb tota la creativitat, fantasia, teatre i expressivitat possibles, i amb poques imatges. La nostra expressió serà la font principal d'informació : la nostra cara ("eye contact») els prepararà per anar comprenent la prosòdia. Hem d'acostumar els nens sords a veure que la informació comença amb el llenguatge, parlant, amb les paraules.

2) Dramatització del conte:tots els nensiel professor representen el paper de tots icadascun dels personatges. Tots han de viure el conte en tots els sentits. Han de ser I'heroi, l'antagonista, els comparses... En aquesta fase, el nen ha de comprendre clarament la història a base de qualsevol recurs: imatges, ninots, franelograma, gesticulació... tot s'hi val.

3) Es comencen a ensenyar les paraules del conte. És la lliçó, pròpiament dita. Es donen les imatges de la historieta en làmines, diapositives, etc. A cada imatge li correspon una frase. S'ha de repetir i repetir fins a memoritzar un petit nombre de paraules i frases que s'aniran modificant d'acord ambel nivell lèxic i sintàctic de cada alumne.

4) Etapa de "teatralització". Cada nen representa un personatge dins de l'escenificació global del conte.

5) Fixació i escriptura del text perqualsevol sistema gràfic i dicció de les paraules per qualsevol procediment semàntic.

6) Privatització del que s'ha après aplicant-ho a l'experiència personal.

7) Creació de la imatge acústica mitjançant la gravació del conte en la "cassette" del nenque, d'aquesta manera, tindrà a casa una aportació activa de tot el que ha treballat a l'aula.

Si els aprenentatges es fonamenten en l'experiència personal de la pròpia creixença, és molt important el treball que pot fer-se sobre la biografia selectiva del nen. A més, se l'ha d'acostumar a imaginar el que no es veu, a observar les coses en llur relació, una rera l'altra, quan aquestes coses són absents i se l'ha d'entrenar en l'exercici de l'evocació amb l'ajuda de gràfics i accions.

Els records són importants en l'estructuració del temps $i$ en la informació del llenguatge. També s'ha d'insistir en l'estructura espai-temps fins $i$ tot abns que els nens tinguin ben adquirit el llenguatge.

Per ajudar els alumnes a adquirir o millorar aquestes capacitats es pot actuar en dos camps:

a) Calendaris gràtics de classe. S'en poden fer cinc de diferents:

1. Representació diària del temps atmosfèric.

2. Assistència dels alumnes.

3. Distribució horària de les activitats setmanals.

4. Representació setmanal dels menús escolars.

5. Representació anual de festes i celebracions.

b) Elaboració d'un diari personal. Per donar exemple, el professor pot escriure un diari de classe $\mathbf{i}$ cada nen el seu propi. Poc a poc, els nens podran explicar la seva vida als altres.

D' altra banda, fent la història global de la classe com a cos, mitjançant els calendaris il.lustrats, els nens van prenent la idea de cos social. La seva vida individual, captiva del seu entron immediat, els impedeix, sovint, atànyer el concepte de societat.

Els calendaris $i$ els diaris els ajuden a establir relacions personals i temporals, a comprendre el pas del temps i a imaginar el passat.

Tot el treball presentat fins aqui fara actuar el nen. L'estructura de la classe ha de permetre fer-hi coses perquè pugui desenvolupar les seves possibilitats. Es comprèn millor allò que es fa o es manipula. Permetent actuar al nen i animant-lo a fer-ho, l'ajudem a aprendre, que es, al cap i a la fi, el nostre objetiu. 